\title{
The Practical Research on English Flipped Classroom Teaching Mode in Higher Vocational Colleges
}

(The research results of CGW15001 the 12th five-year education Science plan project in Shandong province "the practical research on English flipped classroom teaching mode in higher vocational colleges")

Author: Hu Yan, Shandong Vocational College of Light Industry in China,

Key words: Flipped classroom, Higher vocational public English, Experiment

\begin{abstract}
This paper studies the application of flipped classroom teaching mode in higher vocational English teaching. The experimental results show that: In flipped classroom teaching mode, students' English learning achievements have been improved significantly, the students' humanistic quality has been improved obviously. In order to better promote the reform of English teaching in higher vocational colleges and improve the application of flipped classroom teaching mode, the author puts forward some feasible Suggestions.
\end{abstract}

\section{Introduction}

We have entered the era of "Internet+", which has brought a new development of higher vocational education. Under the condition of information globalization, higher vocational students' learning conditions have changed greatly and the popularization of smart phones has become a trend. These smart terminals can run the APP, play video, interact in real time, and lay a material foundation for intelligent learning. At the same time, more perfect infrastructure network, the popularization of campus network, WIFI, and the use of $4 \mathrm{~g}$ networks, make it convenient for students to learn online, and interact with teachers anytime and anywhere.

The sources of students in higher vocational college are complicated, most of them have poor English foundation, being tired of learning English, and have low humanistic quality, low teamwork spirit, poor autonomous learning ability. In class, teachers work hard, but students do not respond, resulting in poor interaction between them, passive atmosphere, and poor teaching effect. In the traditional English teaching mode, students' English application ability and comprehensive quality goals are difficult to achieve. Therefore, it is imperative to change the backward teaching mode and use the flipped classroom teaching mode in the public English teaching, which is complied with the development of education information and educational reform in higher vocational colleges.

\section{The Teaching Practice of English Flipped Classroom Mode}

The teaching experiment lasted one academic year (September 2016 to July 2017).Four classes (2 experimental classes and 2 control classes) participated in the experiment. In order to ensure the scientific experiment, an English teacher taught four classes, the only difference is that: the flip classroom teaching mode was used in the experimental classes, and the traditional teaching model was used in comparative classes.

The teaching mode of English flipped classroom mainly consists of three parts:

pre-class, in-class and after- class. Students' learning activities include two steps: knowledge acceptance and knowledge internalization. Pre-class is knowledge acceptance, and after-class is knowledge internalization.

\subsection{Pre-Class Teaching Activities.}

\subsubsection{Teachers' Activities}

\subsubsection{Making and uploading the micro course.}

In flipped classroom teaching mode, knowledge is taught through micro-course. When making micro course, teachers should give full consideration to students' learning style, learning habits. To 
stimulate students' interest in learning, and meet their needs, the difficulty of its content should be moderate, and the patterns should be diversified and novel. The recording environment should be quiet to prevent the noise from interfering with students' attention. In addition, we should follow the objective laws of students' physical and mental development, control the time to ensure the best learning effect and efficiency. After finishing the micro course, it should be timely uploaded onto the learning platform online.

\subsubsection{Making and Uploading Autonomous Learning Task List.}

Students' autonomous learning task list can clearly guide students to study independently, so that students can understand what they should learn and how to learn. According to the Recent Development Zone theory, the level of exercises should be moderate, which is in line with students' English level, so as to stimulate their learning motivation and the content should be consistent with the micro-course to help students to consolidate the new knowledge.

\subsubsection{Learning Feedback and Interactive Answering Questions.}

With the help of micro-course, students gain the basic knowledge, but they will meet many confusion and problems in the learning process, then they can ask teachers for help through the Internet (qq or WeChat).To meet students' needs, teachers will design the teaching plan by checking students' task completion online and give helps online.

\subsubsection{Students' Activities}

\subsubsection{Watching Micro Course, and Completing Autonomous Learning Tasks.}

Before class, students are required to watch the micro course. The video is simple and easy to understand, so they can completely control their learning pace and take notes in detail, and mark doubts and difficulties to ask classmates and teachers for help. After watching the video, they complete the online autonomous learning task to consolidate the new knowledge learned from the micro-course and find difficulties.

\subsubsection{Asking Questions and Asking Teachers for Help.}

If a student encounters an incomprehensible knowledge point, he or she can record it and discuss with others, or consult teachers online. At the same time, they can give feedback to teachers to help teaching activities in class.

\subsection{Teaching Activities in Class.}

\subsubsection{Knowledge Consolidation and Problem Solving.}

At the beginning of class, the teacher guides students to review what they have learned from the micro course. Teachers can guide students to review by showing pictures, playing games or role play, telling stories. In a word, teachers should adopt innovative, flexible ways to guide students to consolidate knowledge, then students are required to discuss the questions they meet and put forward solutions by group.

\subsubsection{Autonomous Learning}

After the communication between teachers and students, teachers organize students to study independently and stimulate students' potentials by setting more difficult learning tasks. Autonomous learning ability is an essential skill for college students to develop themselves and adapt to the workplace. In the flipped classroom mode, teachers should offer more autonomous learning environment for students, let them independently think, learn to set up knowledge framework, freely apply knowledge, so as to complete the knowledge internalization.

\subsubsection{Cooperative Learning}

Students should be encouraged to actively participate in cooperative learning activities. By autonomous learning, students have built up their knowledge structure, and if they want to internalize further, they need to communicate with others. In flipped classroom teaching mode, teachers divide students into groups of 5 to 6 . Students should communicate and cooperate with others in the group to complete cooperative learning activities. 


\subsubsection{Exchanging Achievements and Sharing Experience.}

After the completion of a class, students should display their achievements, which can be presented in the form of reports, debates and so on. Through the exchange and sharing, students can learn from each other, can gain the pleasure of learning and enhance their self-confidence.

\subsection{After-Class Teaching Activities.}

Through pre-class, teaching activities in class, teachers should timely summarize and reflect to improve teaching in the future; Students should summarize the whole learning process in order to make progress in the future.

\section{Analysis and Discussion}

The statistics of experimental data show that the English flipped classroom teaching mode has significantly improved students' English level and the humanistic quality. It shows in the following aspects:

\subsection{Students' English Proficiency Has Been Improved Significantly.}

It is obvious that the flipped classroom teaching mode can significantly improve students' English level from the experimental class and the data analysis results of the pre-test and post-test.

\subsection{Students' Interest in English Learning Has Improved Significantly.}

The pre-questionnaire shows students' interest in learning English is very low and even bored. The post-questionnaire shows that students' interest is greatly improved and their confidence grows. Students are interested in watching videos, and they benefit a lot from these interesting learning materials.

\subsection{Students' Autonomous Learning Ability is Significantly Improved.}

The performance of students 'class task and the result of questionnaire data analysis show that students' autonomous learning ability in experimental classes has been significantly improved, students can arrange effective study time and choose the appropriate learning methods according to their own situation.

\subsection{Students' Humanistic Qualities Are Significantly Improved.}

From the students' classroom performance and questionnaire data analysis, in the experimental class, student's communication ability ,team cooperation ability, the ability to solve problems have been improved significantly. The flipped classroom teaching model creates more opportunities for students to present themselves. Students actively participate in group discussions, and actively communicate with teachers and classmates. In order to solve problems, students contribute ideas and Suggestions. All these are conducive to the improvement of students' humanistic qualities.

\section{Advice}

There is no doubt the teaching model is very effective. However, the research also has many limitations: At present, students in higher vocational colleges have not strong independent learning ability, which challenges the effective implementation of flipped classroom teaching model; The quality of micro-course needs to be improved; 
Scientific and reasonable evaluation system should be constructed.

\section{References}

[1]. Cai Yue.2014. Design and Production of Micro-Course [M]. Shanghai: East China Normal University Press.

[2]. Jonathan bergman \& Aaron Sam.2014. Flipped Classroom and Moocs: an Emerging Education Revolution [M]. Beijing: China Youth Publishing House.

[3]. Lin caiying.2014. Research on Teaching Action of English Flipped Classroom in Junior Middle School [D]. Guangxi Normal University.

[4]. Wang caixia and Liu guangan.2013. Analysis of Classroom Teaching in Flipped Classroom Optimization [J]. Education (06):41-44.

[5]. zhang jinlei. Research on Flipped Classroom Teaching Model [J]. Remote Education Magazine.2012,(4),46-51. 